\title{
PENERAPAN MODEL PEMBELAJARAN QUANTUM TEACHING UNTUK MENINGKATKAN HASIL BELAJAR IPA TEMA LINGKUNGAN SAHABAT KITA PADA SISWA KELAS V SDN GIRIMARGO 1 TAHUN AJARAN 2020/2021
}

\author{
Isnanto Sunu Utomo ${ }^{1}$, Wahyudi ${ }^{2}$, Suhartono ${ }^{3}$ \\ Universitas Sebelas Maret \\ isnansunu21@student.uns.ac.id
}

\section{Article History}

accepted 30/8/2021

\begin{abstract}
The study aimed: (1) to describe the steps for implementing the Quantum Teaching model, (2) to improve science learning outcomes, (3) to describe the constraints and solutions. This research is a collaborative classroom action research carried out in three cycles. The subjects of this research are teachers and students. Data collection techniques used was observation, interviews, and tests. Data analysis includes data reduction, data presentation, and conclusions. The results showed that: (1) the application of the Quantum Teaching learning model was carried out in six steps, namely Tumbuhkan, Alami, Namai, Demonstrasikan, Ulangi, Rayakan; (2) the Quantum Teaching learning model can improve science learning outcomes with the theme 8 Lingkungan Sahabat Kita, as evidenced by an increase in the average value of student learning outcomes, which in the first cycle $=82.61$, second cycle $=85.66$, and third cycle $=86$ ,08; (3) the constraints of this research are that students lack confidence, students do not conduct discussions, students are less active, students play alone, and learning media is inadequate. The solution is that the teacher motivates students, guides students during discussions, reprimands students, and teacher prepares the media that will be used before learning is carried out. The conclusion of this study is that the application of the Quantum Teaching learning model can improve science learning outcomes on Lingkungan Sahabat Kita theme for the fifth grade students of SDN Girimargo 1 in academic year of 2020/2021.

Keywords: Quantum Teaching, Learning Outcome, Science
\end{abstract}

\begin{abstract}
Abstrak:
Tujuan penelitian ini yaitu: (1) mendeskripsikan langkah-langkah penerapan model Quantum Teaching, (2) meningkatkan hasil belajar IPA, (3) mendeskripsikan kendala dan solusi. Penelitian ini merupakan penelitian tindakan kelas kolaboratif yang dilaksanakan dalam tiga siklus. Subjek penelitian ini adalah guru dan siswa. Teknik pengumpulan data menggunakan observasi, wawancara, dan tes. Analisis data meliputi reduksi data, penyajian data, dan kesimpulan. Hasil penelitian menunjukkan bahwa: (1) penerapan model pembelajaran Quantum Teaching dilaksanakan dengan enam langkah yaitu Tumbuhkan, Alami, Namai, Demonstrasikan, Ulangi, Rayakan; (2) model pembelajaran Quantum Teaching dapat meningkatkan hasil belajar IPA tema Lingkungan Sahabat Kita, terbukti dengan adanya peningkatan nilai rata-rata hasil belajar siswa, yaitu pada siklus $I=82,61$, siklus $I I=85,66$, dan siklus III= 86,08; (3) kendala penelitian ini yaitu siswa kurang percaya diri, siswa tidak melakukan diskusi, siswa kurang aktif, siswa bermain sendiri, dan media pembelajaran kurang memadai. Adapun solusinya yaitu guru memotivasi siswa, guru membimbing siswa ketika diskusi, guru menegur siswa, dan guru menyiapkan media yang akan digunakan sebelum pembelajaran dilaksanakan. Kesimpulan penelitian ini adalah penerapan model pembelajaran Quantum Teaching dapat meningkatkan hasil belajar IPA tema Lingkungan Sahabat Kita pada siswa kelas V SDN Girimargo 1 tahun ajaran 2020/2021.
\end{abstract}

Kata kunci: Quantum Teaching, Hasil belajar, IPA 


\section{PENDAHULUAN}

Pendidikan merupakan fokus utama dalam upaya menjaga kualitas generasi muda agar memiliki kecakapan dan keterampilan abad 21. Kompetensi abad ke-21 merupakan kompetensi utama yang harus dimiliki siswa agar mampu berkiprah pada kehidupan nyata. Menurut kemendikbud (2017: 5), kompetensi keterampilan abad 21 yang harus dimiliki siswa yaitu: Kreativitas dan inovasi (creativity and innovation), berpikir kritis dan pemecahan masalah (critical thinking and problem solving), komunikasi (communication), dan kolaborasi (collaboration).

Kompetensi abad 21 sudah mulai ditanamkan pada siswa di jenjang pendidikan dasar yang terintegrasi dalam berbagai muatan pembelajaran. IPA merupakan salah satu muatan pelajaran yang tepat untuk menanamkan dan mengembangkan kompetensi keterampilan abad 21. Pembelajaran IPA mengedepankan sikap ilmiah atau perilaku ilmiah seperti jujur, disiplin, tanggung jawab, santun, peduli, dan percaya diri kepada siswa. Pembelajaran IPA memiliki tujuan untuk menyelidiki sekitar guna mengembangkan keterampilan proses, memecahkan masalah, serta mampu untuk mengambil keputusan. Susanto (2016:169) menyatakan bahwa IPA merupakan kumpulan fakta dan konsep maka IPA membutuhkan proses dalam menemukan fakta dan teori yang akan digeneralisasi oleh ilmuwan. Dalam mempelajari IPA diperlukan keterampilan proses serta kemampuan untuk memecahkan masalah dan proses yang panjang guna menemukan fakta. Pada kenyataannya tujuan pembelajaran IPA belum dapat tercapai secara maksimal.

Berdasarkan hasil observasi di SDN Girimargo 1, pembelajaran IPA yang berlangsung di kelas belum optimal. Hal ini dapat diamati ketika pembelajaran berlangsung yaitu: (1) siswa kurang antusias dalam pembelajaran dan kurang memperhatikan penjelasan guru; (2) partisipasi siswa belum menyeluruh; (4) guru masih menerapkan model pembelajaran yang berpusat pada guru.

Permasalahan dalam pembelajaran IPA di SDN Girimargo 1 diperkuat dengan data nilai ulangan harian mata pelajaran IPA tahun ajaran 2020/2021 rata-rata nilai siswa yaitu 62,75. Nilai rata-rata tersebut masih tergolong rendah karena belum melebihi Kriteria Ketuntasan Minimal (KKM) yaitu 70. Dari data siswa yang berjumlah 20 anak, terdapat 14 siswa yang nilainya masih di bawah KKM, sedangkan 6 siswa yang lain sudah memperoleh nilai di atas KKM. Perbandingan antara siswa yang belum tuntas dan yang sudah tuntas adalah $4: 1$. Sedangkan persentase siswa yang tuntas hanya $30 \%$ dari 20 siswa, $70 \%$ dari 20 siswa belum mencapai batas nilai ketuntasan minimal. Oleh karena itu, diperlukan perbaikan pembelajaran pada mata pelajaran IPA. Perbaikan tersebut dapat dilakukan dengan menerapkan model pembelajaran yang sesuai yaitu model Quantum Teaching.

Materi yang dibahas dalam penelitian adalah materi pada tema 8 Lingkungan Sahabat Kita mengenai siklus air dengan KD 3.8 Menganalisis siklus air dan dampaknya pada peristiwa di bumi serta kelangsungan mahluk hidup, yang bersumber dari Peraturan Menteri Pendidikan dan Kebudayaan Nomor 21 Tahun 2016 tentang Standar Isi Pendidikan Dasar dan Menengah. Menurut Mariana dan Praginda (Tursinawati, 2016: 74), IImu Pengetahuan Alam (IPA) merupakan makna alam dari berbagai fenomena yang dikemas menjadi sekumpulan teori dan konsep melalui serangkaian proses ilmiah yang dilakukan manusia. Tujuan dari pembelajaran IPA di sekolah dasar adalah

hasil belajar IPA tema 8 Lingkungan Sahabat Kita merupakan kemampuan kognitif yang diperoleh siswa setelah mengikuti pembelajaran pada KD 3.8 Menganalisis siklus air dan dampaknya pada peristiwa di bumi serta kelangsungan mahluk hidup, dapat diukur dalam aspek kognitif yang terdiri dari empat aspek meliputi: 
(1) mengingat, (2) memahami, (3) menerapkan, (4) menganalisis, yang diukur dari hasil tes evaluasi setelah mengikuti pembelajaran IPA dengan penerapan model pembelajaran Quantum Teaching.

Model Quantum Teaching adalah model yang mengubah segala interaksi dalam momen belajar untuk memunculkan kemampuan dan bakat alamiah siswa dengan menggunakan prinsip sugesti, serta menekankan kreativitas siswa agar lebih aktif dalam pembelajaran. Menurut Yanuarti dan Sobandi (2016: 14) model pembelajaran Quantum Teaching adalah model yang dapat meningkatkan hasil belajar karena menggunakan prinsip sugesti dan menekankan kreativitas siswa agar lebih aktif dalam pembelajaran, sehingga siswa mampu mengembangkan kemampuan yang dimilikinya. Sejalan dengan pendapat tersebut menurut Shoimin (2014: 138) berpendapat bahwa model pembelajaran Quantum Teaching adalah pengubahan belajar yang meriah dengan segala nuansanya yang menyertakan segala kaitan antara interaksi dan perbedaan yang memaksimalkan momen belajar.

Model pembelajaran Quantum Teaching merupakan model pembelajaran yang dinilai mampu menciptakan suasana yang menyenangkan dalam pembelajaran. Menurut Cahyaningrum, Yahya, dan Asyhari (2019: 374) langkah-langkah model Quantum Teaching yaitu: (1) Tumbuhkan, (2) Alami, (3) Namai, (4) Demonstrasikan, (5) Ulangi, (6) Rayakan.

Penerapan model pembelajaran Quantum Teaching pada mata pelajaran IPA disesuaikan dengan karakteristik siswa kelas V SD yang berada pada tahap operasional konkret, dimana anak mampu berpikir sistematis tentang benda dan peristiwa konkret, tetapi masih kesulitan mengungkapkan sesuatu.

Berdasarkan uraian di atas, dapat dirumuskan masalah sebagai berikut: (1) Bagaimanakah penerapan model Quantum Teaching untuk meningkatkan hasil belajar IPA tema Lingkungan Sahabat Kita pada siswa kelas V SDN Girimargo 1 Tahun Ajaran 2020/2021?, (2) apakah penerapan model Quantum Teaching dapat meningkatkan hasil belajar IPA tema Lingkungan Sahabat Kita pada siswa kelas V SDN Girimargo 1 Tahun Ajaran 2020/2021?, (3) apa kendala dan solusi pada penerapan model Quantum Teaching untuk meningkatkan hasil belajar IPA tema Lingkungan Sahabat Kita pada siswa kelas V SDN Girimargo 1 Tahun Ajaran 2020/2021?.

Tujuan penelitian ini yaitu: (1) mendeskripsikan penerapan model Quantum Teaching untuk meningkatkan hasil belajar IPA tema Lingkungan Sahabat Kita pada siswa kelas V SDN Girimargo 1 Tahun Ajaran 2020/2021, (2) meningkatkan hasil belajar IPA tema Lingkungan Sahabat Kita pada siswa kelas V SDN Girimargo 1 Tahun Ajaran 2020/2021 melalui penerapan model Quantum Teaching, (3) mendeskripsikan kendala dan solusi penerapan model Quantum Teaching untuk meningkatkan hasil belajar IPA tema Lingkungan Sahabat Kita pada siswa kelas V SDN Girimargo 1 Tahun Ajaran 2020/2021.

\section{METODE}

Penelitian ini dilaksanakan di SDN Girimargo 1 yang berlangsung dari bulan September 2020 sampai Mei 2021. Subjek penelitian ini adalah guru kelas V dan siswa kelas $\mathrm{V}$ yang berjumlah 20 siswa yang terdiri dari 11 siswa laki-laki dan 9 siswa perempuan.

Penelitian tindakan kelas ini dilakukan secara kolaboratif. Karena penelitian dilaksanakan ketika terjadi pandemi virus covid-19, penelitian dilaksanakan secara luring di kediaman guru kelas, guna mematuhi protokol kesehatan, maka siswa yang masuk dibagi menjadi 2 kloter pada tiap pertemuan, siswa perempuan pada jam pertama dan siswa laki-laki pada jam kedua. Data yang digunakan berupa data 
kualitatif yaitu penerapan model pembelajaran Quantum Teaching dan data kuantitatif yaitu pada tes hasil belajar siswa pada mata pelajaran IPA. Teknik pengumpulan data menggunakan observasi, wawancara, dan tes. Validitas data menggunakan triangulasi teknik dan sumber. Teknik analisis data meliputi reduksi data, penyajian data, dan kesimpulan.

Indikator kinerja penelitian ini adalah penerapan model penerapan model pembelajaran Quantum Teaching dan hasil belajar IPA pada tema 8 materi siklus air $(\mathrm{KKM}=70)$ ditargetkan mencapai $85 \%$. Adapun prosedur penelitian ini menggunakan model penelitian tindakan kelas yang terdiri dari empat tahapan, yaitu (1) perencanaan, (2) pelaksanaan, (3) observasi, (4) refleksi.

\section{HASIL DAN PEMBAHASAN}

Penelitian ini dilaksanakan dalam tiga siklus dengan enam kali pertemuan. Langkah-langkah model pembelajaran Quantum Teaching yang sudah dilaksanakan pada setiap siklus yaitu: (a) Tumbuhkan, (b) Alami, (c) Namai, (d) Demonstrasikan, (e) Ulangi, (f) Rayakan. Langkah-langkah yang digunakan oleh peneliti mengacu pada langkah-langkah model pembelajaran Quantum Teaching yang dikutip dari tiga sumber yaitu Cahyaningrum, Yahya, dan Asyhari (2019: 374), Ngalimun (2016: 247), dan Ulandari dan surya (2017: 122) yang pada intinya berpendapat bahwa langkah-langkah model pembelajaran Quantum Teaching terdapat 6 langkah yaitu: 1) Tumbuhkan merupakan tahap menumbuhkan motivasi dan minat siswa terhadap materi; 2) Alami adalah tahap guru mengembangkan pengetahuan awal yang dimiliki siswa; 3) Namai yaitu tahap memberikan konsep atas pengalaman siswa; (4) Demonstrasikan merupakan tahap dimana siswa menunjukkan apa yang telah mereka ketahui, dapat berupa penyajian di depan kelas, menjawab pertanyaan, dan menunjukkan hasil pekerjaan; (5) Ulangi adalah tahap dimana guru menekankan kembali materi; (6) Rayakan merupakan tahap dimana siswa mendapat pengakuan akan perolehan keterampilan maupun ilmu pengetahuan, bentuk pengakuan dapat berupa verbal maupun non-verbal.

Hasil observasi penerapan model pembelajaran Quantum Teaching mengalami peningkatan pada setiap siklusnya hingga mencapai indikator kinerja penelitian yang ditargetkan sebesar $85 \%$.

Tabel 1 Perbandingan antar siklus Hasil Observasi Penerapan Model Pembelajaran Quantum Teaching terhadap Guru dan Siswa

\begin{tabular}{|c|c|c|c|c|c|c|c|c|}
\hline \multirow{2}{*}{$\begin{array}{l}\text { Langkah } \\
\text { Penerapan Model } \\
\text { Quantum Teaching }\end{array}$} & \multicolumn{2}{|c|}{ Siklus I } & \multicolumn{2}{|c|}{ Siklus II } & \multicolumn{2}{|c|}{ Siklus III } & \multicolumn{2}{|c|}{ Rata-rata } \\
\hline & $\begin{array}{c}G \\
(\%)\end{array}$ & $\begin{array}{c}\mathrm{S} \\
(\%)\end{array}$ & $\begin{array}{c}G \\
(\%)\end{array}$ & $\begin{array}{c}\mathrm{S} \\
(\%)\end{array}$ & $\begin{array}{c}\mathrm{G} \\
(\%)\end{array}$ & $\begin{array}{c}\mathrm{S} \\
(\%)\end{array}$ & $\begin{array}{c}G \\
(\%)\end{array}$ & $\begin{array}{c}\mathrm{S} \\
(\%)\end{array}$ \\
\hline Tumbuhkan & 95,83 & 93,75 & 95,83 & 93,75 & 95,83 & 95,83 & 95,83 & 94,44 \\
\hline Alami & 82,5 & 85 & 87,5 & 85 & 95 & 95 & 88,33 & 88,33 \\
\hline Namai & 77,5 & 75 & 85 & 87,5 & 87,5 & 87,5 & 83,33 & 83,33 \\
\hline Demonstrasikan & 89,77 & 90,9 & 92,02 & 90,9 & 95,4 & 93,15 & 92,4 & 91,65 \\
\hline Ulangi & 87,5 & 89,06 & 88,75 & 89,06 & 88,75 & 90,62 & 88,33 & 89,58 \\
\hline Rayakan & 80 & 82,5 & 90 & 95 & 95 & 95 & 88,33 & 90,83 \\
\hline Rata-rata & 85,32 & 86,04 & 89,08 & 90,2 & 92,91 & 92,85 & 89,43 & 89,7 \\
\hline
\end{tabular}

Berdasarkan tabel 1 dapat diketahui bahwa persentase penerapan model Quantum Teaching terhadap guru dan siswa mengalami peningkatan pada tiap siklus. Pada siklus II dan siklus III rata-rata hasil observasi guru dan siswa sudah mencapai 
indikator kinerja penelitian yang ditargetkan yaitu 85\%. Dengan demikian dapat dikatakan bahwa penerapan model pembelajaran Quantum Teaching sudah tepat, dan sesuai dengan langkah-langkah model Quantum Teaching.

Tabel 2 Perbandingan Antar siklus Hasil Belajar Siswa IPA tema 8 materi siklus air

\begin{tabular}{|c|c|c|c|c|c|c|}
\hline \multirow[t]{2}{*}{ Keterangan } & \multicolumn{2}{|c|}{ Siklus I } & \multicolumn{2}{|c|}{ Siklus II } & \multicolumn{2}{|c|}{ Siklus III } \\
\hline & Pert. 1 & Pert. 2 & Pert. 1 & Pert. 2 & Pert. 1 & Pert. 2 \\
\hline Nilai Tertinggi & 100 & 100 & 100 & 100 & 100 & 100 \\
\hline Nilai Terendah & 40 & 36,67 & 40 & 36,67 & 46,67 & 46,67 \\
\hline Rata-rata & 81,75 & 83,47 & 85,33 & 85,98 & 84,99 & 87,16 \\
\hline Tuntas (\%) & 90 & 85 & 95 & 95 & 95 & 95 \\
\hline Belum Tuntas (\%) & 10 & 15 & 5 & 5 & 5 & 5 \\
\hline
\end{tabular}

Berdasarkan tabel 2 dapat dilihat bahwa hasil belajar siswa meningkat dari siklus I sampai dengan siklus III. Siklus I pertemuan 1 nilai tertinggi yang diperoleh sebesar 100 , nilai terendah sebesar 40 , rata-rata nilai siswa 81,75 dengan siswa tuntas sebanyak 18 siswa dan siswa tidak tuntas sebanyak 2 siswa. Siklus I pertemuan 2 nilai tertinggi yang diperoleh sebesar 100 , nilai terendah sebesar 36,67 , rata-rata nilai siswa 83,47 dengan siswa tuntas sebanyak 17 siswa dan siswa tidak tuntas sebanyak 3 siswa. Siklus II pertemuan 1 nilai tertinggi yang diperoleh sebesar 100 , nilai terendah sebesar 40, rata-rata nilai siswa 85,33 dengan siswa tuntas sebanyak 19 siswa dan siswa tidak tuntas sebanyak 1 siswa. Siklus II pertemuan 2 nilai tertinggi yang diperoleh sebesar 100 , nilai terendah sebesar 36,67, rata-rata nilai siswa 85,98 dengan siswa tuntas sebanyak 19 siswa dan siswa tidak tuntas sebanyak 1 siswa. Siklus III pertemuan 1 nilai tertinggi yang diperoleh sebesar 100, nilai terendah sebesar 46,67, rata-rata nilai siswa 84,99 dengan siswa tuntas sebanyak 19 siswa dan siswa tidak tuntas sebanyak 1 siswa. Siklus III pertemuan 2 nilai tertinggi yang diperoleh sebesar 100 , nilai terendah sebesar 46,67, rata-rata nilai siswa 87,16 dengan siswa tuntas sebanyak 19 siswa dan siswa tidak tuntas sebanyak 1 siswa.

Berdasarkan penjelasan di atas, maka dapat disimpulkan bahwa penerapan model pembelajaran Quantum Teaching dapat meningkatkan hasil belajar IPA pada tema Lingkungan Sahabat Kita materi siklus air, yang dilihat dari persentase siswa yang memenuhi ketercapaian target dari siklus I - III. Menurut Yanuarti dan Sobandi (2016: 14) Peningkatan hasil belajar ini terjadi karena dalam penerapan model pembelajaran Quantum Teaching merupakan model yang menggunakan prinsip sugesti dan menekankan kreativitas siswa agar lebih aktif dalam pembelajaran, sehingga siswa mampu mengembangkan kemampuan yang dimilikinya. Penelitian ini sejalan dengan penelitian yang dilakukan Verawati, Kitong, dan Sasingan (2020: 98) berdasarkan hasil penelitian yang telah dilakukan dapat diketahui bahwa dengan menerapkan model pembelajaran Quantum Teaching dengan langkah TANDUR dapat meningkatkan hasil belajar IPA di kelas V Sekolah Dasar Penelitian relevan lainnya yaitu penelitian yang telah dilakukan oleh Suwandari, dan Susarno (2014: 10) yang menyatakan bahwa penerapan model pembelajaran Quantum Teaching mampu meningkatkan hasil pembelajaran serta aktivitas guru dan siswa dalam kegiatan pembelajaran.

Kendala dalam penelitian ini yaitu: (1) terdapat beberapa siswa yang berbicara sendiri sehingga mengganggu jalannya proses pembelajaran, (2) terdapat siswa yang tidak melakukan diskusi ketika mengerjakan tugas kelompok, (3) media atau fasilitas kurang memadai, (4) siswa kurang aktif dalam memberikan tanggapan hasil diskusi, 
(5) masih terdapat siswa yang malu dalam menjawab pertanyaan, dan kurang percaya diri dalam memberikan tanggapan.

Adapun solusi dari kendala yang ditemui selama penelitian yaitu: (1) guru meningkatkan penguasaan pengelolaan kelas, (2) guru membimbing siswa agar mau bekerja sama dengan membagi tugas dalam memecahkan masalah dalam kelompok, (3) sebelum pembelajaran dimulai guru mempersiapkan jauh hari agar media pembelajaran serta fasilitas lain yang mendukung pembelajaran siap digunakan (4) guru mengkondisikan siswa agar saat presentasi siswa saling menanggapi, (5) guru memberikan motivasi agar siswa lebih percaya diri.

Kendala yang muncul sesuai dengan kelemahan model Quantum Teaching sesuai dengan yang dikemukakan Shoimin (2014: 146) menguraikan bahwa model Quantum Teaching memiliki beberapa kelemahan antara lain: (1) memerlukan kesiapan dan perencanaan yang matang serta waktu yang cukup panjang, yang mungkin terpaksa mengambil waktu atau jam pelajaran lainnya, (2) memerlukan keterampilan guru secara khusus karena tanpa ditunjang hal itu, proses pembelajaran tidak akan berlangsung secara efektif, dan (3) agar model ini berjalan dengan baik diperlukan ketelitian dan kesabaran. Adapun solusi yang diberikan berdasar dari pendapat yang dikemukakan oleh Akbar dan Pramukantoro (2014: 107) yaitu kesulitan yang dihadapi dalam menggunakan model Quantum Teaching akan terjadi dalam situasi dan kondisi belajar yang kurang kondusif sehingga menuntut penguasaan kelas yang baik.

\section{SIMPULAN}

Peningkatan hasil belajar IPA tema 8 Lingkungan Sahabat Kita materi siklus air melalui model pembelajaran Quantum Teaching pada siswa kelas V SDN Girimargo 1 tahun ajaran 2020/2021 dilaksanakan dengan langkah-langkah: (a) Tumbuhkan, (b) Alami, (c) Namai, (d) Demonstrasikan, (e) Ulangi, (f) Rayakan.

Penerapan model pembelajaran Quantum Teaching dapat meningkatkan hasil belajar IPA tema 8 materi siklus air pada siswa kelas V SDN Girimargo 1 tahun ajaran 2020/2021.

Berkaitan dengan hasil penelitian yang telah dicapai, terdapat implikasi secara praktis, yaitu penelitian ini dapat dijadikan dasar bagi guru untuk menentukan model pembelajaran guna meningkatkan hasil belajar siswa. Salah satu model yang tepat adalah model pembelajaran Quantum Teaching.

\section{DAFTAR PUSTAKA}

Akbar, M. S., Pramukantoro, J. A. (2014). Pengaruh Model Quantum Teaching Terhadap Motivasi Siswa pada Standar Kompetensi Dasar-Dasar Elektronika di SMK Nu Sunan Drajat Paciran Lamongan. Jurnal Pendidikan Teknik Elektro, 3 (1), 105.

Cahyaningrum, A. D., Yahya, A. D., dan Asyhari, A. (2019). Pengaruh Model Pembelajaran Quantum Teaching Tipe TANDUR Terhadap Hasil Belajar. Indonesian Journal of Science and Mathematics Education. 02 (3) 372.

Ngalimun, Fauzani, M., Salabi, A. (2016). Strategi dan Model Pembelajaran. Banjarmasin: Aswaja Pressindo.

Peraturan Menteri Pendidikan dan Kebudayaan Republik Indonesia Nomor 21 Tahun 2016 Tentang Standar Isi Pendidikan Dasar dan Menengah.

Peraturan Menteri Pendidikan dan Kebudayaan Republik Indonesia Nomor 22 tahun 2006 tentang Standar Isi Pendidikan.

Shoimin. (2014). 68 Model Pembelajaran Inovatif dalam Kurikulum 2013. Yogyakarta: Ar ruzz Media. 
Susanto, A. (2016). Teori Belajar dan Pembelajaran di Sekolah Dasar. Jakarta: Kencana Prenadamedia.

Tursinawati. (2016). Penguasaan Konsep Hakikat Sains dalam Pelaksanaan Percobaan pada Pembelajaran IPA di SDN Kota Banda Aceh. Jurnal Pesona Dasar, 2 (4), 72.

Ulandari, L., Surya, E., (2021). Improving Learning Outcomes of Linear Program with Quantum Teaching Model at Grade X Students SMK-BM PAB 3 Medan Estate. International Journal of Science: Basic and Applied Research (IJSBAR), 33(3), 120.

Verawati, A.Y., Kitong, O. E., Sasingan, M. (2020). Efektivitas Penggunaan Model Quantum Teaching dalam Meningkatkan Hasil Belajar IPA. Journal of Education Technology. Vol. 4(2), 96.

Yanuarti, A., dan Sobandi, A. (2016). Upaya Meningkatkan Hasil Belajar Siswa Melalui Penerapan Model Pembelajaran Quantum Teaching, Jurnal Pendidikan Manajemen Perkantoran, 1 (1),11. 